\title{
Film Business in Bangladesh: A Historical Account
}

\author{
Md. Mohiuddin \\ Associate Professor Department of Management Studies Jagannath University, Dhaka-1100, Bangladesh.
}

\begin{abstract}
Film is the wonderful industry and powerful organ of mass media in the present world. This unique mass media becomes the container and carrier of society, civilization, history, tradition and culture. It is equally popular in Bangladesh, like other countries. In 1895,Lumiere Brothers son of Antoa Lumiere invented cinematograph with the combinations of camera and projector. On 28 December in 1895 they showed the first cinema by the cinematograph. This date is the red-letter day in the history of cinema. Hira Lal Sen was the first film shower and maker in the history of film in Bengal and also in undivided India. He formed a company which was named as The Royal Bioskop Company in 1898. He arranged the first film show in the then East Bengal (now Bangladesh) on 4th April 1898, in Bhola of Barishal. After the War of Independence, Bangladesh started to making film for commercial purposes. This study is conducted to find out the history of film business in Bangladesh. Film making is very expensive which is made in any studio, now it establishes as film industry, so it was made and showed for commercial purpose from it's birth.
\end{abstract}

Keywords: Bangladeshi film, Film making, Film showing, Film business history.

\section{Introduction}

Film is the great contribution of science, it has vast technological, commercial, social, managerial sector. There is no debate about this unparallel art media as the most modern artistic branch of mass media of present century. It preserves time, space, objective reality and subjective expression. It is a popular culture because it has own universal language. The film originates in cross- currents of the ninetieth and twentieth century. Today, like other countries, it is equally popular in Bangladesh and there is no debate about this unparallel art media as the most modern artistic branch of mass media of the present century. Film is nothing but 'moving still photography'. When 24 numbers in a frame of a still photography is reflected per second on the screen by a projector then we can see the picture is moving. It is closely related with persistence of vision. Light is the core element of it. Greek scientist Aristotle in 384-322B.C and P. Tolemy of Alexandria in 130 A.D discovered the phenomenon of persistence of vision. Then Arcimidis in 287-219 B.C opened the door of light and lens in his research. Accordingly, scientist Ucleed discovered that "Light travels in a straight line". This was the main theme of camera. In 1250 Leon Battista Alberti invented forerunner of camera obscura . World famous artist, scientist and philosopher Leo Nardo Da Vinchi described the 'camera obscura'first time. In 1693, delaporta made camera by the use of vinchi's camera obscura system. The idea that still photography can move was totally an unknown phenomenon. In 965-1038, famous Arabic scholar and philosopher Ibne-Al Haiten disclosed a research result about the persistence of vision.

\section{Objective}

The objective of this work is to examine the historical growth and development from early stage to present stage of film business in Bangladesh. The study will aim at understanding particular in history of film making and film showing in this country which was directly or indirectly involved in film business.

\section{Methodology}

For this work data and information will be collected from secondary sources. Data have been collected from books, journals, magazines and film related publications.

\section{Film Showing and Making Brief History in Undivided Bengal}

Augusta Lumiere and Lui Lumiere, sons of Antoa Lumiere were the inhabitant of France. They showed cinema in the Indian Ballroom of Grand Café, Paris, on 28th December in 1895. That day is the first film showing day in the world film history. After successful showing, they and their company started film showing in various countries in the world. Moris Sesister representative of Lumiere Brothers, showed cinema by the cinematograph in Watson Hotel at Bombay (Mumbai) on 7th July in 1896 in undivided India. The show was organized by the Persian businessman H.J. Punewala.

On 18th January 1896 Tomas Hadson showed cinematograph and on 19th January in the same year, Arther Sulivan showed Animetograph in Dalhausi Institiute of Kolkata. But J.J Stevension showed first cinema 
in Hatibagan's Star Theatre at Kolkata on 29th October 1898. That day was the first film showing day in undivided Bengal. Prof. Father Lanfo, Moreno and Amrito Lal Sen were the organizers of the first film showing in undivided Bengal.

Hira Lal Sen was the first film shower and maker in the history of film in Bengal and also in undivided India. He formed a company which was named as The Royal Bioskop Company in 1898. He arranged the first film show in the then East Bengal (now Bangladesh) on 4th April 1898, in Bhola of Barishal. He showed film at the Banglo of S.D.O of Bhola first. On 17th April 1898 he showed cinema at 'Crown Theatre' in Dhaka near Shadarghat organized by Bordford Cinematograph Company. The price of ticket for this show were minimum eight ana and maximum three rupees. At that time, it became the means of entertainment for middle as well as upper class public.

In 1899,HiraLal Sen's 'Royal Bioskop Company' purchased and brought Bioskop machine, and movie camera from the 'Wick Trading Company' of London .he had keen interest in making film. At last in 1901, he snapped of three theatre drama's selective portion by movie camera. Those dramas were Bankim Candra's 'Seeta Ram', Tarakanath's 'Subala' and 'Ali Baba'. He also captured the attention of crowd and passengers of moving tram of Cheetpur road in celluloid and showed it to public commercially.

'Encyclopedia of Indian Cinema' edited by Palwl Wailman and Ashis Rajadhaka cited that dancing picture of the 'parasser ful' drama was captured in clluloide by Hiralal Sen,was the first film making and his 'Royal Bioskop Company' was also the first filmmaking institution of Indian Sub-Continent. On 21 August in 1903, the newspaper ' Banglabasi' commented that royal bioskop company had snapped photography of movable scenery and showed movie. 'Jaba Kusum Oil' was the first advertisement film of Hira Lal Sen. He made 12 story films, 10 documentary films and 3 advertisement films. Films of Hira Lal Sen had a length of 50 to $250 \mathrm{ft}$ for the duration of 1 minute to 5 minute.

Dungi Raj Gobinda Falke(Dada Bhai Falke) made a film of $3100 \mathrm{ft}$ length named 'Raja Harish Chandra' in 1913. It was the first full length cinema in India. He established 'Indian Film Company' in Bombay (Mumbai) in1917. He made 100 movies, that's why Indian cinema earned an individual identity and also enjoyed the commercial movie.

During this decade many film making studio were established in Bombay (Mumbai), Kolkata ,and Madraj, many commercial films were made in these places. Our national poet Kazi Nazrul Islam made a film named 'Dhrubo'in collaboration with Sattendra Nath Day, he was the first Bengali Muslim who made a film as a director, scriptwriter, music director and singer. Obaidul Haque(Himadry Chowdhury) made 'Dukhe Jader Jibon Gora' at Kolkata in 1946. Udayan Chowdhury(Ismail Mohammad) made the film 'Manuser Vogoban'. Thus Bengali filmmaker made many films in Kolkata specially.

\section{V. $\quad$ Film Making in Bangladesh Territory- The Initial Days}

Although it is not as advanced as Kolkata, Bombay and Madraj; Dhaka was not in that backward in film making. The younger members of the Nobab family in Dhaka were the initiators of film making. They established a production house in the name of 'Dhaka East Bengal Cinematograph Society'. They thought that they could make film with the proper utilization the talent of local artists, technologists and other facilities. They made two films, the first was 'Sukumari' a short length film of 4 reels in 1927-1928. The second was 'The Last Kiss' a full-length film of 12 reels in 1931. Both were soundless and dialougeless cinema, directed by Ambuj Gupta, who was the physical teacher of Jagannth College(Now Jagannath University). The then Vice-Chencellor of Dhaka University Professor Romesh Chandra Majumder inaugurated the first show of 'Last Kiss'. It was released first in Mukul Cinema Hall(Now Azad) and its showing continued for one month. Arura film company took this film for greater distribution but was not successful.

A temporary studio was established in Nobab's garden at Azimpur in Dhaka for filmmaking, 1929. It was enriched with English and Urdu sub-title. Khaja Azmal was the main actor and cameraman, Khaja Nasrullah, Khaja Adil, KhajaAkmal, Khaja Shahid, Khaja Jahir, Sailen Roy were the actors of the 'Last Kiss'; Lolita(Buri), Charubala, Deb Bala, Harimoti were the actress of cinema. But it is a matter of regret that there is no reel or any document in Bangladesh Film Archive, except some still photography.

\section{Film Making in Pakistan Period (1947-1971)}

After the division of India a new state Pakistan was born in 1947. Bengal was divided into two parts, one as East Bengal was in Pakistan and another was West Bengal in India. East Bengal was named East Pakistan and Dhaka became its capital. Dhaka started cultural activities as a new area. Many persons and organizations took initiative in film making. Muslims people came from Kolkata, Bombay and other places to Dhaka for film making.

Nazir Ahmed was the famous Radio personality; he made a documentary film on Mohmmad Ali Jinnah in 10 days stay in East Pakistan. He brought instruments and technicians from 'Orora Film Studio' of Kolkata and processed it in Kolkata and he edited this film. Subtitle of this film was in three languages I.e. Bangla, 
English and Urdu and was named 'In Our Midst'. This was released in the month of April-May in 1948, it was the first sound and documentary film in East Pakistan and today's Bangladesh. Mr.Najir Ahmed was made the chief of this newly opened film unit. He made a documentary film named 'Salamat'of 4 reels in 1954, he was not only the first documentary film maker and also the pathfinder of filmmaking in Dhaka. Abdul Jabber Khan, Md. Modabber and Mr. Mohiuddin formed 'Iqbal Films' in 1954. Started to making film without any studio and laboratory facilities, also proved that our soil was fit for filmmaking and threw a challenge to West Pakistan. Abdul Jabber Khan made the first full length story named 'Mukh-O-Mukhush' at Dhaka in1954 which was released for showing on 3 August in1956. This is the history of film making in Dhaka before the establishment of East Pakistan Film Development Corporation (EPFDC). The then Industry and Commerce Minister Sheikh Mujibor Rahman raised a bill named East Pakistan Film Development Corporation (EPFDC) in the Provincial Legislative Council on 3rd April ,1957 and the bill had passed. Accordingly, East Pakistan Film Development Corporation (EPFDC) established at Tejgoan ,Dhaka in the same year. That was the great achievement for East Pakistan to making film; film makers became busy with making film in Dhaka.

Foteh Lohani was the first filmmaker of EPFDC and made film named 'Asia' which was awarded as the best Bangla Film in Pakistan and was released later on in 1960. During Pakistan period many films were made and earn lot of money. Jahir Raihan made Pakistan 's first color film named 'Sangam'(Urdu) in 1964. Slahuddin's 'Rupban' was popular and Jahir Raihan's 'Bahana' was the first cinemascope movie.Day by day filmmaking had increased and makers made movie with full stimulation and 34 movies had released in 1968. In 1970 just before the independence war the highest number (41) of movies had released from EPFDC.

During the War of Independence filmmaking had not stopped Jahir Raihan made a documentary film 'Stop Genocide' and it was the first film of Independent Bangladesh and some documentary had made under his leadership. Abdul jobber khan organized and formed Film Department under the Expatriate Government of Bangladesh and also got financial assistance by the government for film. Many foreign filmmakers inclined to making motion picture about our War of Independence, of them came and captured the real scenario of issues and events on the Independence War of Bangladesh and some filmmakers made documentary film and movie.

\section{Film Making in Bangladesh}

After the War of Independence, Bangladesh started to reconstruction and development in every sector of the country, film sector also started to make film. The researcher found in the historical analysis of this study, it shows that film makers made different classified film based on the theme of Muktijudho, literature, social, folk, action, children, history, comedy, adventure, fantasy, national awakening, biography etc. and try to find out the probable classification of Bangladeshi film during 1990s and those films focused our society and culture in different aspects which express itself as a popular entertainment i.e.-

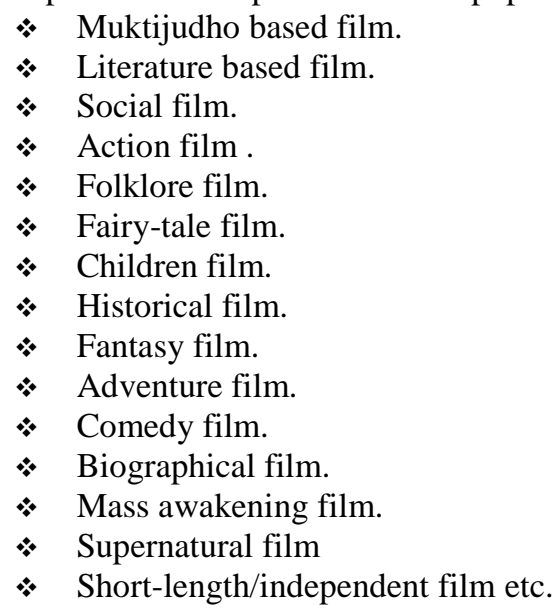

Various classes films are making during (1972-1990) in Bangladesh are given in the bellow table-1:

Table: 1

\begin{tabular}{|l|l|l|}
\hline \multicolumn{1}{|c|}{ Sl. No. } & \multicolumn{1}{c|}{ Types of Film } & No. of Film [Release Period] \\
& & \multicolumn{1}{c|}{} \\
& & \\
\hline 1. & Muktijudho Based Film & 22 \\
\hline 2. & Literature Based Film & 20 \\
\hline 3. & Social Film & 25 \\
\hline 4. & Action Film & 18 \\
\hline
\end{tabular}


Film Business in Bangladesh: A Historical Account

\begin{tabular}{|l|l|l|}
\hline 5. & Folklore film & 17 \\
\hline 6. & Fairy -tale film & 47 \\
\hline 7. & Children film & 12 \\
\hline 8. & Historical film & 04 \\
\hline 9. & Fantasy film & 15 \\
\hline 10. & Adventure film & 03 \\
\hline 11. & Comedy film & 07 \\
\hline 12. & Biographical film & 03 \\
\hline 13. & Mass awakening film & 05 \\
\hline 14. & Supernatural film & 03 \\
\hline 15. & Short-length film & 25 \\
\hline
\end{tabular}

After 1990s and up to the present period of this century same trend of film making has found but the trend of making violence, terrorism and sexuality films have started which is still continuing in this decade of the present century except some good films. The effect of Satellite, Dish, private TV channel, Disc; film makers try to make sex and violence films for surviving of competition with dish, disc and others as a result Bangladeshi films have lost own trend as a popular culture and will be converted as a lower class entertainment, though trying to back its goodwill by various steps but the position is not remarkably improve.

\section{Conclusion}

This study was conducted to see the historical background and the emergence of film business. This article describes the pre-history of film making, film making and showing history in Indian Subcontinent, film making in Bangladesh territory in initial days, Pakistan period (1947-1971), film making in Bangladesh. Lumiere Brothers made and showed first film in the world on 28 December in 1895 and they showed movie commercially in Indian Subcontinent on 7 July in 1896. Hiralal Sen showed first film on the 4 April, 1898 East Bengal. He made and showed film for commercial purpose and established Royal Bioscop Company which was familiar with a popular entertainment and opened a new dimension of business. This study shows that we have a long but rich tradition and cultural heritage of film and film business which is still continuing with various problems but film is the wonderful industry and powerful organ of mass media in Bangladesh till today.

\section{References}

[1] Hayat, A , Bangladesher Cholochchitrer Itihas, ( Bangladesh Film Dedevelopment Corporation(BFDC), Dhaka, 1987)

[2] Hayat, A , Cholochchitra Bidhya ( Bangladesh Film Study Centre, Dhaka 2004) pp-13-14.

[3] Mokammel, T, Cholochchitra Kotha (Bangladesh Film institute, Dhaka,2007)

[4] Nasreen, G. and Haq, F, Bangladesher Cholochchtro Shilpo Sangkote Jonosangskriti (Shrabon Prokasoni, Dhaka,2008)

[5] Roy, S, Bisoy Cholochchitro (Ananda Publishers (Pvt) Ltd, Kolkata,1976)

[6] Rahman, B, Cholochchtrer Vasa ( Dhaka,1985)

[7] Senal, A, Cinemar Itikotha, ( M.C.S \& S (Pvt) Ltd, Kolkata,2003) p-1. 